\title{
Konflikt pomiędzy nauką a wiarą w polityczno- -ideologiczny konsensus w sprawie globalnego ocieplenia
}

DOI: 10.19195/1643-0328.22.11

Słowa kluczowe: globalne ocieplenie, konsensus naukowy, konsensus polityczny, racjonalność naukowa, racjonalność polityczna

\section{Wprowadzenie}

Problem globalnego ocieplenia osiągnął współcześnie status, który uniemożliwia dyskusję nad względnie neutralną rolą człowieka w zmianach klimatycznych, ponieważ dominuje fundamentalna retoryka $\mathrm{z}$ przeważającym przesłaniem alarmującym, zmierzającym do wprowadzenia regulacji w gospodarce światowej $\mathrm{w}$ celu ograniczenia emisji gazów cieplarnianych. Intencją tekstu nie jest spór z klimatologami. O skali dominacji dowodu, który, co najmniej pragmatycznie, zmusza do uznawania jego arytmetycznej doniosłości, świadczy fakt, że 97\% spośród klimatologów uznaje konsensus w sprawie globalnego ocieplenia. Bez wątpienia klimatolodzy badający wpływ człowieka na zjawisko globalnego ocieplenia mają ogromny pod względem merytorycznym dorobek. Już sam ogrom ich pracy zasługuje na najwyższy szacunek. Być może są nawet o krok od całkowitej pewności, wyrażonej empirycznym dowodem, że problem ocieplenia klimatu jest funkcją życia i gospodarowania człowieka. Jeśli założenia klimatologów się sprawdzą, nieuniknione będą konsekwencje, być może o charakterze nieodwracalnym. Wciąż jednak brakuje owych 3\%, których wątpliwości sytuuje się na marginesie życia naukowego.

Owa dysproporcja zachęca do przyjrzenia się retoryce wątpiących $\mathrm{w}$ realiach debaty naukowej, przeniesionej na grunt dyskursu politycznego. W takim aspekcie niniejszy tekst dotyka zagadnienia globalnego ocieplenia jako wyrazu woli i konsensusu mającego cechy polityczne, natomiast weryfikacja hipotez ściśle klimatologicznych pozostaje po stronie specjalistów w tej dyscyplinie. Ich olbrzymi dorobek nie będzie w tym tekście analizowany ani kwestionowany. Chodzi jedynie o zbadanie tego, jak wiedza specjalistyczna wykorzystywana jest w debacie politycznej, która pozoruje często argumenty naukowe, względnie wykorzystuje je rzekomo bez utraty ich właściwości ściśle naukowych. Do tego celu stosuję analizę metateoretyczną. Ten wybór zdaje się interesujący poznawczo. 
Nie zmienia to faktu, że sam główny problem stanowi oręż w walce pomiędzy ideologiami: lewicową i konserwatywną. Bezzasadne staje się wykorzystanie do oceny zjawiska argumentacji obu obozów, które właściwie nie mają sobie już nic do powiedzenia. Wpływają one w równym stopniu na sposób odbioru treści tego ekologicznego przesłania. To nie jest wybór między tym, kto chce dbać o środowisko naturalne, a tym, kto nie chce. Ciekawszy zdaje się ów bezalternatywny dyktat skrajności, czego owocem jest choćby handlowa segregacja uprzednio sortowanych odpadów, podczas gdy dla liberałów liczy się chęć życia zgodnie z naturą i dbanie o czystość środowiska. Nasze myślenie determinuje pytanie o to, czy chcielibyśmy istnienia zjawiska globalnego ocieplenia. Odpowiedź obu stron najpewniej byłaby przecząca, przy czym nie oznacza to, że skoro przyroda nie ma wzorców postępowania dla człowieka ${ }^{1}$, to należy ją dewastować, choćby poprzez niekontrolowaną wycinkę drzew ${ }^{2}$.

Celowo narracja prowadzona jest z perspektywy retoryki kwestionującej prostą zależność między działalnością człowieka a ocieplaniem się klimatu, ponieważ istnieje znaczna nierówność w debacie na korzyść antropocentrycznie ujętego paradygmatu globalnego ocieplenia. Zauważmy, że emisję dwutlenku węgla traktuje się jako głównego sprawcę zmiany temperatury na Ziemi. O ile nie należy tego stanowiska bezrefleksyjnie kwestionować, o tyle warto jest stawiać pytanie o to, czy nie mamy do czynienia jedynie z warunkiem sprzyjającym - czy emisja dwutlenku węgla stanowi okoliczność wpływającą czy konieczną?

Są to pytania wprost odnoszące się do metodologii badań nauk przyrodniczych, jednak przynajmniej częściowo mogą one pochodzić z debaty wokół problemu, mającej postać stricte polityczną. Publiczna dyskusja wpływa bezpośrednio na motywacje badaczy, zwłaszcza kiedy będziemy pamiętać o pozycji ekologii jako uznanego i często spójnego programu politycznego zorientowanych na tę problematykę ugrupowań politycznych. Odnoszę się do reguł debaty, w mniejszym stopniu zaś do jej przedmiotu. W żadnym momencie tekst ten nie stawia odbiorcy przed wyborem: dbać czy nie dbać o środowisko naturalne. Tego typu alternatywa jest bezprzedmiotowa zarówno w ujęciu teoriopolitycznym, jak i typowo ludzkim. Chodzi wyłącznie o wykazanie, że racjonalność teoriopolityczna, a przede wszystkim ujęcie metateoretyczne nie pozwalają zająć stanowiska w sporze, który zawsze ma wymiar ideologiczny.

Rodzą się oczywiście pytania: czy niemal bezalternatywny dyskurs nie ogranicza prawa do wypowiedzi innej niż przyjęty powszechnie kierunek. Czy potrafimy jeszcze rozmawiać o istocie debaty, nawet $\mathrm{w}$ tak newralgicznym sektorze jak zdrowie i życie człowieka, bez politycznego afektu? Do tego celu używam założeń teorii nauki i z ich

1 A. Bloom, Umysł zamknięty, Poznań 2012, s. 228.

$2 \mathrm{~W}$ debacie na temat wycinania drzew wskutek obowiązywania tzw. lex Szyszko użyto argumentu, że $1 \mathrm{~m}^{3}$ drzewa pochłania tonę dwutlenku węgla i produkuje $800 \mathrm{~kg}$ tlenu. Abstrahując od wiarygodności tego twierdzenia, nie mówi ono przecież, ile tlenu drzewa zużywają w ramach oddychania mitochondrialnego, jak również nie informuje się o fakcie, że drzewostan nie zmienia swojej wydajności gazowej pod wpływem większej emisji dwutlenku węgla - tego rodzaju wątpliwość teoretyczna nie jest równa zgodzie na wycinkę drzew, które mogą w fazie wzrostu pełnić również wiele dodatkowych, a ważniejszych niż paliwo opałowe, funkcji. 
perspektywy dotykam utrwalonego konsensusu w sprawie globalnego ocieplenia. Obiektywne ustalenia w tekście dotyczą wyłącznie założeń epistemologicznych, natomiast, jak dotąd, nie udało się uzyskać niekwestionowalnej wiedzy teoretycznej w obszarze politologii, co oczywiście nie czyni naszych starań beznadziejnymi.

Narzędzi poznawczych użyto w taki sposób, aby wskazać na wątpliwości co do korzyści z przeniesienia debaty o globalnym ociepleniu z laboratoriów do publicznej przestrzeni, gdzie mieszają się podejścia potoczne i naukowe. Tak prezentowana wiedza o opisywanym problemie zyskała status obiektywnej, przesłaniając prawa poznania naukowego, jakim winny być poddawane wszelkie ludzkie dociekania w obszarze poznania naukowego. W tekście globalne ocieplenie nie jest opisywane jako zjawisko obiektywne z dwóch powodów. Pierwszy to oparcie się klimatologów na konsensusie, a drugi to uczynienie tego problemu częścią tego, co polityczne. Natomiast pojęcie „wiary w globalne ocieplenie" użyte zostało w rozumieniu teologii polityki jako zsekularyzowany odpowiednik biblijnego dnia sądu ${ }^{3}$.

Czy uzasadnienie naukowe może mieć podstawy oparte na przeświadczeniu o jego niewątpliwej słuszności? Tym samym jako istotę dowodu uznaje się wiarę w osiągnięcie jakiegoś skutku społecznego w postaci wywołania zachowań, które są zbiorowo przyjmowane za „właściwe”. Efektem tych dociekań nie jest już poznanie naukowe par excellence, lecz wyznanie swoistej wiary w słuszność i bezkonkurencyjność stanowisk, deklaratywnie uznanych za naukowe, ale będących jakąś formą sądów moralnych. Równolegle obserwujemy postawy wyrażające otwartą niechęć do ideologii, zastępujące ją określeniem utylitaryzmu poznawczego, dla którego prawda rzekomo nie ma i nie może mieć żadnej alternatywy ${ }^{4}$. Uzasadnienie ideologiczne odnosi się przede wszystkim do chęci osiągnięcia celu, jaki niekoniecznie mieści się jeszcze w polu badań nauki, pierwotnie odnoszącej się do problemu. W ten sposób takie tematy, jak aborcja czy efekt cieplarniany i globalne ocieplenie, nie dotyczą już kwestii medycznych i nauk o ziemi, lecz stają się istotnym elementem postulowanych praw społecznych.

Konsensus polityczny kreuje dogmat dotyczący niemożliwości obalenia twierdzenia o podnoszeniu się średnich temperatur na Ziemi wskutek nieodpowiedzialnego zachowania człowieka. Pod względem teoriopoznawczym mamy tu do czynienia z zastosowaniem odwrotności Marksowskiej przepowiedni. Tym niemniej materializm historyczny przetrwał tu pod inną postacią, doprowadzając do sytuacji braku możliwości rozwoju społecznego, którą zaczerpnął z rozwoju i opanowania praw natury ${ }^{5}$, jako daleko posunięta analogia do procesów przyrodniczych ${ }^{6}$.

Wniosek towarzyszący wyznawcom wiary w globalne ocieplenie polega na twierdzeniu, że rozwój ludzi zostanie zatrzymany z powodu niemożliwości wypełnienia pierwszego warunku, czyli istnienia sekwencyjnej przyrody i jej rozkwitu. Jeżeli postęp dialek-

3 Por. C. Schmitt, Teologia polityczna i inne pisma, Kraków 2000, s. 60.

4 Por. A. Kołakowska, Wojny kultur i inne wojny, Warszawa 2015, s. 45.

5 Por. R. Panasiuk, Człowiek wobec przyrody, „Acta Universitatis Lodziensis - Folia Philosophica” 1993, nr 10, s. 11.

6 A. Schaff, Obiektywny charakter praw historii: z zagadnień marksistowskiej metodologii historiografii, Warszawa 1955, s. 26. 
tyczny uzależniony był m.in. od przetworzenia przyrody, to jej ewentualna degradacja uniemożliwia rozwój sił wytwórczych, ogranicza więc zdolności jednostek do „zbiorowego kontrolowania własnych środków istnienia"7.

Leszek Nowak zauważał, że marksizm tak rozciągnął pojęcie sił wytwórczych, aby umieścić $\mathrm{w}$ nim wiedzę naukową ${ }^{8}$. Działo się tak z bardzo prozaicznego powodu. Jeśli zakładano określony stan pożądany, jaki miał zdarzyć się w przewidywalnej przyszłości, a to traktowano dogmatycznie, to nie mogła istnieć okoliczność (nauka) kwestionująca założenia, na jakich ufundowany był sam pogląd materialistyczny. Wątpliwości musi jednak budzić przypuszczenie, że zdolni bylibyśmy do przewidzenia nie tylko tempa i kierunku odkryć naukowych, ale wręcz tego, co konkretnie zostanie odkryte. W interesującym nas przypadku ekolodzy-walczący musieliby posiąść umiejętności upoważniające ich do twierdzenia na temat tego, co na pewno nie zostanie odkryte (dowód zaprzeczający hipotezom), a ewentualnie mogłoby odwrócić niekorzystną tendencję ekosystemu.

Tadeusz Klementewicz prezentując swoje założenia "geopolityki trwałego rozwoju”, przywołuje m.in. teorię Malthusa, której ogólna prawidłowość została zakwestionowana wskutek rozwoju gospodarczego, społeczno-demograficznego, a także zdobyczy nauki ${ }^{9}$. Mamy tu zatem do czynienia $\mathrm{z}$, anonsowanym przez autora $\mathrm{w}$ innymi miejscu, epistemologicznym umiarkowanym antynaturalizmem ${ }^{10}$. Przekładając to na język politologii, Klementewicz jest sceptyczny wobec empirycznej adekwatności naszej profesji w relacji do nauk przyrodniczych. Jego stanowisko wydaje się jednak więcej niż przydatne w odpowiedzi na nadmierną ufność w sprawczą moc człowieka, nawet jeśli w omawianym przykładzie jest ona wyłącznie autodestrukcyjna.

W relacji do tego zjawiska wielu badaczy stara się ignorować naukowe dowody głoszące, że żyjące niegdyś na ziemi organizmy nie przetrwały, mimo że nie osiągnęly zdolności wytwarzania artefaktów. Zwolennicy hipotezy sprawczej, wskutek braku poważniejszych dowodów, decydują się na strategię aproksymatyczną. Niemożność uzgodnienia naukowego zastępuje się formalnie unaukowionym sądem opartym o ekoprzepowiednię. Istnieje zatem wiara $\mathrm{w}$ to, że człowiek jest $\mathrm{w}$ stanie wpływać na przyrodę, ale wyłącznie dewastując ją, a nie opanowywać jej degradację poprzez wrodzoną intensywność poznawczą.

Marksiści zasłynęli z całkowitej negacji maltuzjanizmu, w którym naturalistyczny wzrost demografii kontrastował z materialistycznym rozwojem cech społecznych. Tadeusz Klementewicz przywołuje dwie hipotezy pochodzące ze współczesnych dokonań nauki o ziemi: hipotezę Medei oraz Gai. Pierwsza zakłada, że każdy gatunek ma naturalną skłonność do rywalizacji o przetrwanie w biosferze. Organizmy najlepiej przystosowane odpowiadają ewoluowaniem na zmieniające się warunki życia na ziemi, co skutkuje roz-

7 Por. E. Balibar, Filozofia Marksa, Warszawa 2007, s. 117-118.

${ }^{8}$ L. Nowak, U podstaw teorii socjalizmu, t. 1. Własność i władza, o konieczności socjalizmu, Poznań 1991, s. 244.

${ }_{9}$ Por. T. Klementewicz, Geopolityka trwałego rozwoju: ewolucja cywilizacji i państwa w trakcie dziejotwórczych kryzysów, Warszawa 2013, s. 86.

10 T. Klementewicz, Rozumienie polityki: zarys metodologii nauki o polityce, Warszawa 2011, s. 23. 
rostem gatunku aż do poziomu, w którym zaczyna on niszczyć własne środowisko ${ }^{11}$. Druga z kolei reprezentuje twierdzenie o ewolucji biosfery, optymalizującej warunki do istnienia coraz większej liczby gatunków lub wytwarzania coraz większej biomasy ${ }^{12}$. Co ciekawe, żadna z powyższych hipotez nie „daje wiary” w ewolucyjną adaptację człowieka, który przystosowuje się do niekorzystnie zmieniających się warunków, bo przecież trudno za taki uznać wniosek o ewentualnym zmniejszeniu ilości i rodzajów pożywienia $^{13}$. Sprzężenie zwrotne odciska piętno wyłącznie na jednej ze stron ${ }^{14}$. Rzecznicy globalnego ocieplenia redukują jednak swoje przypuszczenia, tak więc w domenie konsensusu mieszczą się jedynie niemoc ziemi i człowieczy (jako indywidualne wcielenie zła) przesyt konsumpcyjny. Receptą, jaką się popularyzuje, nie jest unifikacja życia człowieka i przyrody, lecz zamiana jednych ludzkich zabawek (np. silników spalinowych) w inne ekozabawki (silniki hybrydowe i np. technologię blue efficiency). Oczekuje się zatem powstrzymania się od określonych działań człowieka, który miał przecież technologicznie czynić przyrodę przedmiotem i miejscem ich realizacji.

\section{Perspektywa teoriopoznawcza}

Debata ekologiczna prowadzona jest w oparciu o normatywne ujęcie problemów społecznych. Poprzedza ją twierdzenie o braku wyboru w postaci stylu życia, którego istotą byłoby lekceważące traktowanie środowiska naturalnego. Zadekretowano bowiem związek przyczynowo-skutkowy pomiędzy czynnikami warunkującymi zmiany klimatu, przy czym uznano jedyny i obowiązujący kierunek tej implikacji:

\section{$\mathrm{CO}_{2}$ (implikuje) wzrost temperatury na Ziemi}

Nie istnieją jednak przekonujące dowody ani na ów związek, ani na poprawność takiego następstwa ${ }^{15}$. Robert Dahl i Bruce Stinebrickner uważają, że naukowa debata przetransponowana na język politycznego osądu może częściowo zmieniać założenia normatywne w twierdzenia empiryczne ${ }^{16}$. Uwagę tę można skonfrontować ze stwierdzeniem Friedricha von Hayeka odnoszącym się do specyficznego obowiązku poznawczego po stronie badacza: „gdy uczony podkreśla, że studiuje obiektywne fakty, ma na myśli to,

11 T. Klementewicz, Geopolityka trwałego rozwoju..., s. 47.

12 Ibidem.

13 Pouczający przykład stanowi problem z uprawą bananów. Istniejąca do lat 50. XX w. odmiana Gros Michael stanowiła według coraz mniej licznych świadectw kulinarny rarytas. Jednak jej uprawa niemal całkowicie zanikła z powodu rozwoju choroby panamskiej (wywoływanej przez grzyby), atakującej rosnące banany. Obecnie analogiczny problem zaczyna dotyczyć spożywanych przez nas od lat bananów odmiany Cavendish, co również grozi ich całkowitym wyginięciem. Mamy zatem do czynienia z konfrontacją przyrody-producenta i człowieka-konsumenta. Tym razem jednak człowiek nie jest winny, ale to na nim spoczywa konieczność wynalezienia antidotum na chorobę panamską.

14 Por. T. Klementewicz, Geopolityka trwałego rozwoju..., s. 47.

15 Por. A. Kołakowska, op. cit., s. 61.

16 R. Dahl, B. Stinebrickner, Współczesna analiza polityczna, Warszawa 2007, s. 195-196. 
że stara się badać rzeczy niezależnie od tego, co ludzie o nich myślą lub z nimi robią"17. Zatem naukowy osąd dotyczący globalnego ocieplenia staje się par excellence politycznym. Odnosi się bowiem bezpośrednio do perswazyjnego języka narracji, która ma cele ściśle polityczne. Wówczas każde twierdzenie zbieżne z oczekiwaniami przedstawicieli paradygmatu zalicza się na konto wzmocnienia samego dowodu.

Truizmem jest przypominać, że wyjaśnianie i/lub rozumienie polityki en bloc stanowi główny zasób naukowy politologów. W związku z tym badanie treści normatywnych oraz empirycznych, jakie pojawiają się w języku polityki, może zabezpieczać roszczenia do naukowości wywodu ${ }^{18}$. Przyjrzyjmy się konsekwencjom reguły zastosowanej przez Dahla i Stinebricknera, której parafraza mogłaby brzmieć: „chciałbym, aby ludzie nie zatruwali naszej planety"19. Zdanie to tylko pozornie nosi znamiona normatywno-empiryczne. Dzieje się tak, ponieważ empiryczny dowód na korzyści płynące $\mathrm{z}$ ograniczenia emisji dwutlenku węgla zakłada kontrfaktyczny sąd o świecie bez nadmiaru jego zawartości w atmosferze ziemskiej. Tylko ewentualna obecność tego drugiego warunku uzasadnia owo pragnienie. Występująca w tym przykładzie polityczna racjonalność opiera się rzekomo na racjonalności nauk przyrodniczych. Wątpliwość, jaka tu powstaje, nie jest odrębnym sądem politycznym, o odmiennych motywacjach ideologicznych, lecz wyłącznie sądzeniem o podstawach prawdziwości wiedzy naukowej. To roszczenie jest tu zasadniczym formatem ideotwórczym. Konsensualny charakter prawdy o globalnym ociepleniu, nie tylko świadomie ignorujący zakres wiedzy empirycznej, przeczy hipotetyczności wiedzy, w której, jak zauważa Grobler ${ }^{20}$ : „o najmocniej naukowo uzasadnionej hipotezie, czyli o żadnym mniemaniu opartym na naukowych podstawach, nie można wiedzieć, że jest prawdziwe".

Konsensus w sprawie zjawiska globalnego ocieplenia ${ }^{21}$ zakłada prawdziwość przeświadczenia o jego spodziewanych skutkach oraz głównych podejrzanych. 97 na 100 klimatologów opisuje negatywny wpływ ekstensywnej aktywności gospodarczej człowieka na klimat. Już ta arytmetyczna racjonalność, pozornie bliska optimum, wyłącznie zasłania na moment fakt niemożności naukowego rozpoznania prawdziwości zdania, które prezentuje. Musiałaby bowiem istnieć niezależna od podmiotu poznającego prawda, co wyrażone jest Popperowską epistemologią bez podmiotu poznającego (obiektywna prawda należąca do trzeciego świata ${ }^{22}$. Tymczasem w przypadku klimatologów prawda jest pochodną ontycznej funkcji samego ich dociekania, stanowiąc wytwór oraz skutek badań. Jest, ponieważ chcą jej badacze klimatu Ziemi.

17 F. von Hayek, Nadużycie rozumu, Warszawa 2013, s. 29.

18 Wymaga to istotnego zastrzeżenia. Stwierdzenia normatywne mogą być częścią analizy dyskursu w politologii. Czymś odmiennym jest jednak stosowanie języka normatywnego w wypowiedziach, które mają na wyrost ambicje naukowe. Zjawisko to dawno już przestało być marginalne w piśmiennictwie politologicznym.

19 Por. R. Dahl, B. Stinebrickner, op. cit., s. 196.

20 A. Grobler, Dwa pojęcia wiedzy: w strone unifikacji, „Przegląd Filozoficzny - Nowa Seria” 25, 2016, nr 1 (97), s. 141-142.

${ }^{21}$ Zob. Mit: Nauka nie jest zgodna w temacie globalnego ocieplenia, http://www.skepticalscience.com/ arg_globalne-ocieplenie-konsensus-naukowy.htm (dostęp: 31 października 2016).

22 Por. K.R. Popper, Wiedza obiektywna: ewolucyjna teoria epistemologiczna, Warszawa 2012, s. 148-150. 
Niezależnie od tego nadal mamy do czynienia z domniemaniem, opatrzonym zastrzeżeniem idealizacyjnym oraz klauzulą ceteris paribus (nie zachodzą nieuwzględnione okoliczności wyjątkowe) ${ }^{23}$. Tak duża liczba zdecydowanych badaczy, z których każdy opiera swoje twierdzenia na istnieniu „niezmienionych okoliczności”, jedynie podnosi stopień wątpliwości. Na znaczeniu zyskuje fakt, że klimatolodzy z laboratoriów przenoszą się do przestrzeni politycznej, gdzie duża część twierdzeń opiera się na sądach normatywnych. Nastąpiło zatem odwrócenie kolejności zaproponowanej przez Maxa Webera naukom społecznym, aby uprzedzenia i przyzwyczajenia wnosić do badań, lecz wyniki prezentować maksymalnie niezależnie od tych pierwszych ${ }^{24}$. Uwikłanie w sądy o charakterze moralnym i politycznym dezawuuje w równym stopniu naukę, niezależnie czy są to badania społeczne czy badania ziemi.

Nie mniej istotna dla naszych rozważań jest, uzupełniona przez Adama Groblera o warunek stosowalności, klasyczna definicja wiedzy: „,wiedzieć coś, znaczy m.in. umieć posiadaną wiadomość zastosować do rozwiązania jakiegoś problemu, teoretycznego lub praktycznego" 25 . Ponownie odwołując się do teorii trzech światów Karla R. Poppera, Grobler zastrzega, że pomija ona świat społeczny, co w konsekwencji uniemożliwia rozwiązywanie problemów społecznych przy pomocy wiedzy z zakresu nauk społecznych ${ }^{26}$. Ostatnia uwaga stanowi bardzo interesującą perspektywę dla rozważań dotyczących prezentowanego powyżej zagadnienia.

Samo zjawisko globalnego ocieplenia zalicza się prawdopodobnie do wiedzy z zakresu nauk przyrodniczych. Trzeba jednak wskazać na hipotetyczność tego mariażu badawczego. Rzecz w tym, że na dziś nie istnieje wiedza, która byłaby wolna od mniemań. Grobler przypuszcza, że co do zasady trudno dokonać dosłownej Popperowskiej deontologizacji wiedzy ${ }^{27}$. Innymi słowy - zawsze, przynajmniej potencjalnie, ktoś może wiedzę przyjąć i wykorzystać. O ile możemy założyć, że mniemanie wpływa na sam proces formułowania wiedzy, o tyle, w przypadku problemu ocieplania się klimatu, to nie mniemanie (belief) poprzedza sam proces formułowania wniosków badawczych, lecz zaangażowanie (commitment) w konkretny program badawczy ${ }^{28}$. Wsparcie tego ostatniego wymusza na reprezentantach działania, które mogą być, wskutek błędnej identyfikacji przez odbiorcę, potraktowane jako składnik jego mniemania ${ }^{29}$.

Powstaje zatem kolejny kłopot, ponieważ biorcy treści naukowych nie potrafią już samodzielnie rozsądzić, co jest wiedzą uzasadnioną, a co wciąż podlega odkryciu. Co więcej, przestają mieć jakiekolwiek wątpliwości w następstwie nadpodaży autorytetów, rozstrzygających to za nich. Stąd wątpliwość dotycząca omawianego zakresu wiedzy klimatologów, która należałaby wyłącznie do dziedziny nauk przyrodniczych. Oni sami

23 Por. A. Grobler, op. cit., s. 142; idem, Metodologia nauk, Kraków 2006, s. 128.

24 C.G. Christians, Etyka i polityka w badaniach jakościowych, [w:] Metody badań jakościowych, red. N.K. Denzin, Y.S. Lincoln, t. 1, Warszawa 2009, s. 212.

25 A. Grobler, Dwa pojęcia wiedzy..., s. 152.

${ }^{26}$ Ibidem (wraz z przypisem nr 7).

27 Por. ibidem, s. 151.

28 Ibidem, s. 152.

29 Ibidem. 
wciągają bowiem odbiorców w obszar programu, nie tylko poprzez arytmetyczny iloczyn, ale przede wszystkim przez upolitycznienie dowodu. Możemy sobie wyobrazić, że np. trzecia zasada dynamiki Newtona nie ma bezpośrednich implikacji politycznych, chyba że poruszające się w konkretnym kierunku ciało osiągnie wartość i cel militarny, kiedy napotka inne ciało (vide rakieta konwencjonalna i przeciwrakieta Patriot).

Stosując rygorystycznie reguły krytycznego racjonalizmu Poppera, można bez trudu dokonać falsyfikacji wiedzy dotyczącej globalnego ocieplenia. Jeżeli jej wartość naukowa obowiązuje prawdziwie dopiero w domenie wpływów nauk społecznych, ponieważ funkcjonuje jako zjawisko polityczne (konsensus), to należałoby wykluczyć przede wszystkim samą postać dedukcyjną. Nie jest dostępna definicja globalnego ocieplenia, która nie rodziłaby skutków społecznych, a więc byłaby rozstrzygana poza działaniem politycznym. Istniejący problem jest w najwyższym stopniu polityczny, a stan ten oznacza jego poznawcze apogeum. Równolegle falsyfikacja twierdzenia o niebezpiecznym wpływie dwutlenku węgla została „histerycznie” odrzucona, ponieważ wiedzę o problemie uznano za niepodważalną. Istnieje przekonanie graniczące z pewnością, a ewentualny błąd, w poczuciu wyznawców, nie będzie rodzić bezpośrednich skutków. Ergo: nie zaszkodzi chronić środowisko naturalne poprzez ograniczenia emisji substancji wytwarzanych przez światowe gospodarki.

\section{„Pełna zgoda co do...?"}

Pewnym wyjaśnieniem fenomenu utrwalania się teorii globalnego ocieplenia może być kwestia niedemokratyczności nauki. Opisał to Michał Heller, wskazując na konieczność istnienia związku dodatniego, gdzie znacząca liczba badaczy — „przeciętnych wyrobników" - spowoduje pojawienie się geniuszy, którzy zagwarantują postęp w nauce ${ }^{30}$. $\mathrm{W}$ omawianym przypadku następuje odwrócenie tego domniemania, czego efektem będzie tym razem demokratyczna reguła „konsensusu cieplarnianego”, a jej wykładnią stanie się aprecjacyjny charakter równouprawnienia w twierdzeniu tego, co nieudowodnione. Przyrosty po stronie wyznawców paradygmatu globalnego ocieplenia zdają się wskazywać, że większość znaczących badaczy klimatu i Ziemi żywi uzasadnione przekonanie, iż obserwowany wzrost średnich temperatur zapowiada globalną katastrofę. Na dowód słuszności owego myślenia badaczom i popularyzatorom mitu globalnego ocieplenia przyznawane są nagrody ${ }^{31}$. Demokratyczna nauka pozwala włączyć na poziomie instytucjonalnym kolejnych wyznawców. Czy zatem fakt braku zaszczytów dla głoszących odmienny pogląd opiera się na stosownej ewaluacji naukowej? Wielcy popularyzatorzy mitu zostają przeciwstawieni tym, którzy kwestionują konsensus i degradują środowisko naturalne.

Fałszywą będzie hipoteza, że im więcej ludzi nauki prezentuje umówioną jednomyślność, tym mocniejszy staje się rzekomy dowód. Pamiętamy, że w prakseologicznym języku polityki również brak potwierdzeń dowodu jest uznawany za jedno z jego naj-

30 M. Heller, Granice nauki, Kraków 2014, s. 181-182.
31 Por. A. Kołakowska, op. cit., s. 52-53. 
mocniejszych uzasadnień. Bierze się to z faktu, że polityczne narracje zakładają zerojedynkowo tylko połowę prawdopodobieństwa, celowo ignorując odmienne możliwości.

Wyobraźmy sobie indyka, który codziennie dostaje paszę. Każde karmienie utwierdza ptaka w przekonaniu, że w jego życiu obowiązuje pewna ogólna zasada: przyjaźni przedstawiciele rasy ludzkiej codziennie go karmią, ponieważ „jego dobro leży im na sercu”, jak powiedziałby polityk. W środę po południu, tuż przed Świętem Dziękczynienia, indykowi przydarzy się coś ni e oczekiwa ne go. Będzie musiał zrewidować swoje poglądy ${ }^{32}$.

Jedyne, co daje się z dużym prawdopodobieństwem przewidzieć, to przyszłe protesty ekologów. Niczego innego dowieść nie sposób, tak długo, jak długo swoje wnioski wyciągamy jedynie z nieodległej przeszłości, w odniesieniu do jednej poddawanej obserwacji zmiennej. Ludzie uznają racjonalność naukową za nadrzędną, jednak o wiele łatwiej przychodzi im to w sytuacji, kiedy wnioski naukowe nie kontrastują z ich oczekiwaniami na ten temat. Richard P. Feynman zwykł stan ten tłumaczyć poprzez relację nauki do świata, powszechnie uznawanego przez nas za rzeczywisty:

Zawsze twierdziłem, że nauka istnieje w oderwaniu od rzeczywistości. [...] Oczywiście nauka ma odniesienie do rzeczywistości, choćby dlatego, że ma odniesienie do astrologii takie mianowicie, że nasze rozumienie świata wyklucza prawdziwość zjawisk astrologicznych. W tym aspekcie nauka nie jest czymś oderwanym. Dla ludzi jednak, którzy wierzą w astrologię, takiego związku nie ma, ponieważ naukowcy nigdy nie zaprzątają sobie głowy omawianiem z nimi tego problemu. Ludzi, którzy wierzą w cudowne uzdrowienie nauka zupełnie nie obchodzi, ponieważ nikt z nimi nie dyskutuje ${ }^{33}$.

W rezultacie wiary w proste następstwo przyczynowo-skutkowe budowane są profetyczne prognozy dotyczące końca konwencjonalnego życia człowieka. Ten rodzaj ideologicznej galwanizacji twierdzeń przeczy przede wszystkim fallibilizmowi, a więc założeniu, że każda wiedza jest odwoływalna. Popper zauważył, sięgając do trylematu Friesa, że twierdzeń nie należy traktować dogmatycznie, ponieważ oznacza to nieuniknioną arbitralność takiego rozstrzygnięcia, lecz starać się je uzasadniać34. Jednak proces ten poprzez odwoływanie się do kolejnych zestawów zdań bazowych prowadzi do regressus ad infinitum - albowiem zdania muszą być uzasadnione jedynie przez zdania ${ }^{35}$.

Wobec powyższego można by spróbować przyjąć perspektywę psychologizmu, a więc uznać, że uzasadnienie polegać może także na wykorzystaniu doświadczeń postrzeżeniowych ${ }^{36}$. Sam Popper wątpił także w tę ostatnią strategię epistemologiczną, ponieważ nie istnieją spostrzeżenia zmysłowe, które nie byłyby pochodną hipotez i teorii, gdyż same pojęcia uniwersalne używane do opisu nie są korelatem żadnego doświadczenia zmysłowego $^{37}$. Uteoretyzowanie obserwacji warunkuje nasz system obserwacji, nie sposób bowiem odzwierciedlić zjawisk bez wcześniejszych, ukształtowanych przez poznane teorie, oczekiwań ${ }^{38}$.

32 N.N. Taleb, Czarny łabędź: o skutkach nieprzewidywalnych wydarzeń, Warszawa 2014, s. 83.

33 R.P. Feynman, Przyjemność poznawania, Warszawa 2005, s. 102.

34 Por. K.R. Popper, Logika odkrycia naukowego, Warszawa 2002, s. 80.

35 Ibidem.

36 Ibidem.

37 Ibidem, s. 81.

38 Por. A. Grobler, Metodologia nauk..., s. 70-71; K.R. Popper, Społeczeństwo otwarte i jego wrogowie, t. 2, Warszawa 2006, s. 269-270. 
Przy takim założeniu samo oczekiwanie katastrofy ekologicznej, zyskującej w mnogich wypowiedziach status apokalipsy, nie zupełnie odnosi się do teorii, lecz raczej do potocznego czy wręcz literacko-fabularyzowanego sądzenia o przyszłości. Oczywiście, można by przypuszczać, że w uproszczony sposób także tu mamy do czynienia z jakąś formą teorii, tym niemniej w praktyce daje się słyszeć spekulatywne sądy, których podstawą jest twierdzenie o wzroście średnich rocznych temperatur, regularnie notowanych dopiero od 1850 r., oparte na odrzuconym przez Poppera wnioskowaniu indukcyjnym. W zamian pozostaje nam Mickiewiczowskie „czucie i wiara”. Nawet jeśliby powiązać wzrost temperatury z przyrostem ilości emitowanego dwutlenku węgla, to wówczas uproszczony model teoretyczny, oparty na związku dodatnim, wymuszałby na nas oczekiwanie radykalnego podniesienia się średnich temperatur, ponieważ emisja $\mathrm{CO}_{2}$ wskutek rozwoju przemysłu i transportu w ostatnich 166 latach musiała przerosnąć wyobraźnię statystycznego badacza wielokrotnie ${ }^{39}$. Fizyka staje się dziś interesującym narzędziem weryfikacji twierdzeń politologicznych.

Weźmy przykład Marsa, którego atmosfera w przeszło 95\% składa się z dwutlenku węgla. Wnioskując przez analogię, należałoby spodziewać się 3200 razy szybszego tempa wzrostu temperatury na powierzchni Czerwonej Planety, ponieważ w normalnym rozkładzie powietrze atmosferyczne Ziemi posiada około $0,03 \% \mathrm{CO}_{2}$. Wówczas identycznie można by dokonać stosownych podsumowań, albowiem 166 lat pomiarów na Ziemi to dla nauk przyrodniczych niewielki okres, choć przez wielu uznawany za miarodajny. Idąc tym tropem, już statystyka kilku lat temperatur na Marsie stanowiłaby zapewne „wiarygodny” dowód.

Przykład ten jest jednak o tyle chybiony, że choćby wartości grawitacji, ilości tlenu w powietrzu, ciśnienia atmosferycznego, marsjańskiego wiatru i wiatru słonecznego są odmienne dla tej planety, natomiast za skok temperatur odpowiadałaby także gęstość („grubość) atmosfery Marsa. Wnioski, jakie z tego płyną, nie pozwalają z podobnym prawdopodobieństwem oczekiwać ziemskiej apokalipsy ani w nią wątpić. Już wnioskowanie przez analogię pozwala zdyskredytować ziemskie sądy potoczne, nawet jeśli wymaga to przeniesienia na inną planetę. Nie chodzi jednak o fakt, że obserwujemy odmienne wyniki w innych warunkach prowadzonego badania. Istotniejsze wydaje się to, że „ziemska” pewność naszego wniosku staje się karykaturą samej siebie. Jest to problem naukowych i geograficznych linii demarkacyjnych, a swoista lokalność sądów uznawanych za naukowe pozwala wierzyć w nie jedynie na mocy bronionego konsensusu. Dowód hic et nunc to dla nauk społecznych coś powszechnego, na dziś nie prowadzimy bowiem badań społecznych poza społecznością ziemską, jednak formalnie uniemożliwia on dążenie do obiektywizacji twierdzeń na poziomie teorii nauki.

39 Według symulacji planowany wzrost temperatur na Ziemi ma przebiegać arytmetycznie $\left(0-6^{\circ} \mathrm{C}\right.$ do 2100 r.). Por. D. Whitehouse, The Global Warming Standstill, The Global Warming Foundation Report 10, 2013, http://www.thegwpf.org/content/uploads/2013/03/Whitehouse-GT_Standstill.pdf (dostęp: 22 października 2016). 


\section{Ocieplanie wizerunku globalnych ekologów}

Skąd zatem twierdzenia o globalnym ociepleniu? Pewnej odpowiedzi możemy szukać w fakcie przyznania w 2007 r. byłemu wiceprezydentowi USA, Alowi Gore’owi, Pokojowej Nagrody Nobla za działania na rzecz przeciwdziałania globalnemu ociepleniu ${ }^{40}$. Brał on również udział w nagrodzonym Oscarem dokumentalnym filmie Niewygodna prawda (An Inconvenient Truth), prezentującym wykład jego samego na temat skutków globalnego ocieplenia ${ }^{41}$. Jarosław Macała pisał o tym:

prawda może i niewygodna, ale film nie stronił od jednostronności czy wręcz manipulacji faktami, straszył nadchodzącym ekologicznym kataklizmem (z tezą, że ludzkość nie przeżyje efektu cieplarnianego) i wzywał do czynu, by do niego nie doszło ${ }^{42}$.

Argument $\mathrm{z}$ autorytetu to, jak mawiają filozofowie, cecha charakterystyczna osób leniwych intelektualnie ${ }^{43}$. Profesor Columbia University, William Happer, fizyk atomowy i przeciwnik uproszczonych sądów o globalnym ociepleniu, wypowiedział 10 maja $2010 \mathrm{r}$. przed Komitetem ds. Niezależności Energetycznej i Globalnego Ocieplenia Izby Reprezentantów USA zdanie o powstaniu ruchu na rzecz walki ze zmianami klimatycznymi: naukowych prawd nie potwierdza się jednak za pomocą opinii, lecz poprzez eksperymenty, obserwacje i testy. Nie znam żadnej dziedziny naukowej, gdzie potrzebny jest udział międzynarodowej organizacji, aby dociec prawdy ${ }^{44}$.

Jednocześnie w swoim wystąpieniu podkreślił, że sąd brytyjski w 2007 r. orzekł, iż wprowadzenie do angielskich szkół publicznych książki Ala Gore’a Niewygodna prawda wymagałoby wyjaśnienia 11 szczególnie problematycznych nieścisłości, takich jak brak związku między huraganem Katrina a dwutlenkiem węgla. Sam film Gore’a opiera się na następującym schemacie: szanowany polityk przywołuje wybrany autorytet naukowy, który uświadomił temu pierwszemu skalę zagrożenia. Efektem zjawiska, uznanego apriorycznie za prawdę, będzie globalna katastrofa klimatyczna. Głosząc bezdyskusyjną „prawdę”, mówca przenosi nas w obszar tego, co subiektywne. Prawda w nauce to obraz wytworzony przez badającego podczas jego spotkania z obiektem badanym. Grzegorz Białkowski w rozmowie z Wiktorem Osiatyńskim wskazywał, że sukces zależy od elastyczności badacza, zmuszonego odrzucić dogmatyczne widzenie rzeczywistości poprzez nieznaną kategorię prawdy:

W.O. - Czy moralna wartość nauki nie polega również na tym, że we współczesnym świecie nauka jest jednym $z$ nielicznych rezerwatów prawdy?

40 http://www.nobelprize.org/nobel_prizes/peace/laureates/2007/ (dostęp: 5 października 2016).

41 An Inconvenient Truth, prod. USA 2006, reż. D. Guggenheim. Zob. M. Lynas, Six Degrees: Our Future on a Hotter Planet, London 2004.

42 J. Macała, Od lekceważenia do trwogi - czyli zmiana klimatu wokół klimatu, „Fabryka wiedzy” 2008, maszynopis w zasobach autora.

43 Por. R. Legutko, Esej o duszy polskiej z posłowiem A.D. 2012, Poznań 2012, s. 154-165.

44 Climate Science in the Political Area, Statement of William Happer, Cyrus Fogg Brackett Professor of Physics Princeton University Before the Select Committee on Energy Independence and Global Warming, 20 maja 2010, http://www.markey.senate.gov/GlobalWarming/files/HRG/052010SciencePolicy/happer.pdf (dostęp: 7 listopada 2016). 
G.B. - Raczej: dążenia do prawdy. Bo uczony nie rości sobie pretensji do jedynej prawdy ani osobistej prawdy. Każdy naprawdę uczciwy uczony jest gotów dać się przekonać. Nawet jeśli upiera się przy prawdzie, to często robi to po to, by adwersarz musiał udoskonalić swój pogląd, oczyścić go z jakichś paprochów umysłowych, a wtedy da się przekonać ${ }^{45}$.

Prawda jest przede wszystkim funkcją ciekawości, ale nie pod postacią gapia i widza, lecz wyłącznie tego, kto docieka ${ }^{46}$. Oczywiście ta dociekana przez byłego wiceprezydenta USA została zwolniona z obowiązku bycia prawdopodobną wersją sądu o zjawisku globalnego ocieplenia. Politycy z natury rzeczy ignorują takie subtelności, ponieważ globalne ocieplenie nie istnieje w narracji politycznej jako „obiektywna wiedza”, lecz „obiektywna wiedza, która przeraża" ${ }^{37}$. Co więcej, ówczesna pozycja polityczna Gore’a miała służyć uwiarygodnieniu jego krucjaty, ponieważ, jako pogodzony z porażką w ramach politycznej doczesności, zajął się wiecznością, poświęcając swoją energię dla przyszłych pokoleń. W filmie nie pada pytanie o sens badania stężenia dwutlenku węgla i wpływ jego wzrostu na podnoszenie się temperatury na Ziemi, lecz mówi się przede wszystkim o dokładności tych badań i posiadanych danych (hard data). Analogicznie brak jest pytań o kierunek oddziaływania, przy założeniu o bezalternatywności przyjętej implikacji. Nikt nie wyraża również wątpliwości związanych z możliwym przypadkowym nakładaniem się faktów w postaci wzrostu temperatur na Ziemi ${ }^{48}$ a emisją i absorpcją dwutlenku węgla. Mieszkając w wieżowcu, można, odrzucając pewne odchylenia, zakładać, że wszyscy żyją w wieżowcach. Wszystko zależy bowiem od kąta patrzenia. Całość staje się prawdziwa mocą samej doniosłości. Dla celów propagandowych kompletnie ignoruje się zdolność przyrody do samoregulacji, ale również konieczność pojawiania się takich faz, niezależnie od aktywności człowieka. Co ciekawe, w tym układzie jedynie ten ostatni uznawany jest za wyłącznego posiadacza systemu immunologicznego.

Nie stanowi nowości w metodologii nauk, że człowiek, pozostając zespolony z naturą jako jej część, poprzez poznawanie zewnętrza, poznaje również samego siebie. Tymczasem Al Gore próbuje nam wmówić, że natura i człowiek to byty antagonistyczne, gdzie niszczycielska moc ludzi stanowi funkcję ich motywacji pozanaturalnych. W kolejnym kroku pewność unaukowionego dowodu uznaje się za kierunek zmian o charakterze politycznym.

W odpowiedzi na film z byłym wiceprezydentem USA powstał m.in. obraz Niespójna prawda (An Inconsistent Truth $)^{49}$. Oczywiście, stronniczość obu pozostaje na podobnym poziomie. Tym niemniej warto odnotować, że narracja budowana jest wokół zysku, jaki jest udziałem ludzi, którzy bogacili się na interesach związanych z globalnym ocieple-

${ }^{45}$ Nauka a świat wartości. Rozmowa z Grzegorzem Białkowskim, [w:] W. Osiatyński, Zrozumieć świat. Rozmowy z uczonymi 25 lat później, Warszawa 2009, s. 72.

46 Ibidem, s. 70.

${ }^{47}$ Nie posiadamy również, co uznać należy za metateoretyczną uzurpację, zdehumanizowanej definicji globalnego ocieplenia.

48 W filmie przywołuje się przykład topienia się czapy lodowej Kilimandżaro, a nie odniesiono się do faktu, że np. naukowcy wciąż spierają się, czy powierzchnia czaszy lodowca Grenlandii faktycznie się zmienia.

49 An Inconsistent Truth, prod. USA 2012, scen. i reż. P. Valentine. 
niem $^{50}$. Trudno zakładać, że majątek zdobyty indywidualnie przez znanego polityka, wskutek promowania pożądanych zmian w zakresie ochrony środowiska, tłumaczy nam cały polityczny fenomen globalnego ocieplenia. Ewentualna skala finansowego dochodu stanowi prawdopodobnie zbyt małą wielkość, aby uznać ją za miarodajną dla opisywanego zjawiska. Zrozumienie motywacji (metodologiczne verstehen) Gore’a można oprzeć o jego polityczny życiorys i wizerunek polityka, jaki przez lata zbudował. Choć wskazywano na skromniejsze od Clintona umiejętności retoryczne, to mimo wszystko był popularnym politykiem. Jeśli pominiemy badanie profilu psychologicznego, wówczas pozostajemy w strefie domniemań. Gore został zapamiętany przez historię jako największy przegrany w walce o fotel 43 . prezydenta USA, co było głównie wypadkową nieprawidłowości, jakie miały miejsce $\mathrm{w}$ głosowaniu w stanie Floryda ${ }^{51}$. Tak więc jego kariera polityczna po roku 2000 naznaczona była tym wydarzeniem. Amerykański system nominacji w wyborach prezydenckich, poza nielicznymi wyjątkami, cechuje się zwykle jednorazową szansą kandydata na urząd prezydenta. W takim ujęciu należy odczytywać kariery amerykańskich polityków, a te nierzadko kończyły się z powodu wyborczej porażki o najwyższy możliwy urząd, przynależny w realiach świata demokratycznego. Wobec tego każda działalność na marginesie tego wyścigu jawi się jako marginalna, nawet jeśli uhonorowana była Pokojową Nagrodą Nobla oraz Amerykańskiej Akademii Sztuki i Wiedzy Filmowej (Nagroda Akademii). Gore został lobbystą ekologicznym, co w szerszej perspektywie może stanowić źródło analizy zaangażowania w sprawy globalnego ocieplenia. Nawet jeśli założymy, że stało się to w sposób pośredni, to jednak bierze on odpowiedzialność za kontekst, jaki tworzył się w wyniku jego działań. Zarzucano mu, że wprowadzenie lansowanych pomysłów radykalnie podniosłoby ceny podstawowych dóbr konsumpcyjnych na świecie oraz skutkowałoby bezrobociem. Nie trudno wnioskować, że przy okazji oznaczałoby to więcej niż znaczące zyski dla dysponentów nowego ekologicznego know-how.

Wyprodukowany przez Leonarda DiCaprio film Before the Flood w jednej z początkowych scen, gdzie aktor spotyka się w siedzibie ONZ z Sekretarzem Generalnym Ban Ki-moonem, koncentruje się na nadaniu DiCaprio nowej roli - „posłańca pokoju ds. globalnego ocieplenia" ${ }^{2}$. Już ta scena zapowiada nie tylko główne przesłanie obrazu, ale również proponuje poziom ważności sądów o zjawisku. Film odnosi się również do sprzeciwów wobec osoby samego aktora jako wiarygodnego ambasadora opisanych treści: „aktywista zastępuje świat nauki, [...] oszukany przez lobby znany aktor z zerową wiedzą naukową" ${ }^{33}$. Oczywiście obraz jest skonstruowany w logice identyfikowania i oceny antagonistycznych obozów. Prezentowane zarzuty z jednej strony odnoszą się do wiarygodności lobbingu bez względu na poziom posiadanej wiedzy, z drugiej zaś expli-

50 Zob. fragment filmu: An Inconsistent Truth, https://www.youtube.com/watch?v=8YtLOQcX-LE (dostęp: 11 listopada 2016).

${ }^{51}$ Jako ciekawostkę można wskazać, że Al Gore uzyskał zarówno lepszy procentowy, jak i bezwzględny wynik głosujących, a to z racji specyfiki systemu wyborczego USA nie oznaczało uzyskania prezydentury.

52 Before the Flood, prod. USA 2016, reż. F. Stevens. W Polsce został wyemitowany przez kanał National Geographic 1 listopada 2016 pod tytułem Czy czeka nas koniec?

53 Ibidem. 
cite wymienia się ludzi i powody upierania się przy negowaniu zmian klimatycznych: „lobby przemysłowe, wykorzystujące paliwa kopalne, neguje globalne ocieplenie”.

Odpowiedzią na ostatni zarzut jest aktywność amerykańskich polityków, którzy otwarcie sprzeciwiają się dyskursywnym faktom ${ }^{54}$. W kontrze zarzuca się im również, że większość blokująca w Izbie Reprezentantów i Senacie USA została kupiona przez koncerny paliwowe ${ }^{55}$. Cechą polityki amerykańskiej pozostaje jej silny związek z odpowiednim otoczeniem sponsorskim w postaci branżowych lobbystów. Informacja o kwotach, jakie przyjęli poszczególni politycy, niezależnie od braku możliwości weryfikacji takiego stwierdzenia, nie stanowi obiektywnego dowodu na chęć „trucia Matki Ziemi”. Jest to daleko idąca insynuacja, kreująca rzeczywistość poprzez film. A gdy do tego dochodzi ideologia, wówczas już nawet nie tyle kreuje się fakty, ile prezentuje własne roszczenie do rzeczywistości ${ }^{56}$. Niełatwo przychodzi nam zrozumieć, że nawet najbardziej przekonujący dokument filmowy nie tworzy obrazu w celu relacjonowania stanu badań w klimatologii, ale właśnie po to, by móc ową wizją świata zmuszać do działań ludzi zdolnych do aktywności politycznej.

Najciekawszym argumentem podnoszonym przez naukowców w filmie DiCaprio jest absorbowanie dwutlenku węgla przez oceany i lasy deszczowe, widziane jako świadome i celowe oddziaływanie. Przyjęto więc intencjonalny i utylitarny cel zachowań przyrody, przejawiający się jej dążeniem do „przeżycia człowieka”. Zupełnie nie bierze się pod uwagę, że pochłanianie dwutlenku węgla może służyć ich rozwojowi naturalnemu, ponieważ w domyśle przyznano lasom i oceanom świadomość ekologiczną, wyrażającą się dążeniem do przetrwania gatunku, który osiągnął wyższy poziom rozwoju od nich, stanowiącego obiektywne dobro ekosystemu. Trudno przyjąć za właściwe założenie, że przyroda intencjonalnie zabezpieczyła się na okoliczność rozwoju współczesnej ekspansywnej gospodarki i jej konsekwencji dla życia ziemskich organizmów. Pochłanianie dwutlenku węgla przebiega nie na skutek jego emisji (zewnętrzne wymuszenie), lecz własnych potrzeb składowych ekosystemu. Zatem konsekwencją lansowania tezy o utylitarnej funkcji lasów i oceanów, będzie implicite wyprowadzony wniosek o nadrzędności praw społecznych nad prawami natury.

Odbierając nagrodę Akademii dla najlepszego aktora pierwszoplanowego (Oscar 2016), DiCaprio skoncentrował się w mowie dziękczynnej na problemie globalnego ocieplenia: „zmiany klimatu są prawdziwe i dzieją się tu i teraz. To jest największe zagrożenie, w obliczu którego stoi nasz gatunek. Nie możemy zwlekać - trzeba wspólnie działać ${ }^{57 "}$. Zrozumiałym jest, że znany aktor stał się w pewien sposób twarzą kampanii na rzecz walki z globalnym ociepleniem. Trudno oczekiwać, że wpisze się on w nauko-

54 Zob. J. Inhofe, The Greatest Hoax: How the Global Warming Conspiracy Threatens Your Future, Washington, D.C. 2012; B. Sussman, Climategate: A Veteran Meteorologist Exposes the Global Warming Scam, Washington D.C. 2010.

55 Before the Flood...

56 Por. K. Minkner, O filmach politycznych: między polityką, politycznością i ideologią, Warszawa 2012, s. 243.

$57 \mathrm{http} / /$ oscar.go.com/news/winners/watch-leonardo-dicaprios-acceptance-speech-for-best-actor-2016 (dostęp: 18 listopada 2016). 
wy kontekst intersubiektywności. Pełni raczej rolę transmitera treści proekologicznych. Tym niemniej sam film sugeruje, że mamy do czynienia z czysto naukową debatą. DiCaprio niczego nie analizuje, nie weryfikuje ani nie falsyfikuje, po prostu odgrywa rolę sumienia amerykańskiego konsumpcjonisty.

Efektem politycznej debaty o ocieplaniu się klimatu Ziemi jest przypisanie człowiekowi roli wyłącznego dewastatora środowiska naturalnego. W takim „klimacie dyskusji” przyjęto za pewnik konieczność zmiany dotychczasowych przyzwyczajeń konsumpcyjnych. Założono, że działanie na rzecz walki z postępującym wzrostem temperatury jest sytuacją bezalternatywną. W ten sposób ogranicza się wolność badań, które mogłyby opierać się o hipotezy samoczynnej regulacji przyrody oraz negatywnych skutków działań człowieka, które zakładają pozytywne efekty w przeciwdziałaniu globalnemu ociepleniu. Ma to o tyle znaczenie, że zarówno działanie, jak i powstrzymywanie się od niego są funkcjami dwuwariantowymi, więc mogą przynosić jednocześnie pozytywne i negatywne rezultaty.

\section{Podsumowanie}

Istotą tego artykułu było zaprezentowanie relacji pomiędzy klasycznymi założeniami nauki a jej ideologicznymi odpowiednikami. Spór pomiędzy doktrynerami a tym, co istotowo naukowe, nie prowadzi bezpośrednio do konfliktu o charakterze politycznym, tym niemniej organizuje sposób debaty o globalnym ociepleniu. Wówczas znaczenia nabierają strategie uwiarygodnienia stanowiska, choć ich bezpośrednim rezultatem jest utrata walorów naukowych. Nie chodzi o fakt, że upolitycznienie problemu znosi możliwości analizy dedukcyjnej, lecz o pewnego rodzaju mistyfikację, która, poprzez przywołanie autorytetów naukowych, ma za zadanie tworzyć wrażenie pewności twierdzeń podnoszonych w społecznie utrwalonej debacie.

Nie było moim celem rozsądzenie o racji którejkolwiek strony. Dalece ważniejsze wydaje się zwrócenie uwagi na postępujące wypieranie wyjaśnienia naukowego afektywnym dowodem, przyjmowanym przez aklamację. Emocje, stanowiące podstawową cechę współczesnych zjawisk politycznych, stają się dziś sentencją wniosków również w naukach przyrodniczych. Naukowcy są częścią politycznej awangardy nie przez to, że ich badania służą procesom opanowywania przyrody, a z racji poparcia ideologicznej wiary w słuszność głoszonych poglądów. Można by w kontrze zaznaczyć, że klimatolodzy nie ponoszą winy za tę cześć politycznych idei, która bezpośrednio zaadaptowana została przez współczesną lewicę. Jednak trudno nie wyrażać wątpliwości, kiedy mariaż ekopolityków i klimatologów skutkuje wymieszaniem twierdzeń naukowych z ich polityczną selektywnością. Charakterystyczne dla nauk ścisłych weryfikacja, konfirmacja oraz falsyfikacja hipotez zastępowane są wyrażeniem zgodnego oświadczenia woli w sprawie zmian klimatycznych na naszej planecie. Nauka bywa wypierana przez wyznanie wiary w globalny konsensus, którego podstawową cechą pozostaje brak zgody na obalenie dyskursywnych prawd, ponieważ konsekwencje polityczne byłyby natychmiastowe i zmieniające tradycyjny układ sił. Sądy te są bowiem wyrażeniem opinii elit i jako takie 
dedykowane społeczeństwu, któremu odebrano prawo do rozstrzygania o ich słuszności. Jedynym sprzężeniem zwrotnym, akceptowanym przez zwolenników wypracowanego porządku, pozostaje bezwarunkowa akceptacja dedykowanych treści politycznych.

\section{Bibliografia}

Balibar E., Filozofia Marksa, Książka i Prasa, Warszawa 2007.

Bloom A., Umysł zamknięty, Zysk i S-KA, Poznań 2012.

Christians C.G., Etyka i polityka w badaniach jakościowych, [w:] Metody badań jakościowych, red N.K. Denzin, Y.S. Lincoln, t. 1, Wydawnictwo Naukowe PWN, Warszawa 2009.

Climate Science in the Political Area, Statement of William Happer, Cyrus Fogg Brackett Professor of Physics Princeton University Before the Select Committee on Energy Independence and Global Warming, 20 maja 2010, http://www.markey.senate.gov/GlobalWarming/files/HRG/052010SciencePolicy/happer.pdf (dostęp: 7 listopada 2016).

Dahl R., Stinebrickner B., Wspótczesna analiza polityczna, Wydawnictwo Naukowe Scholar, Warszawa 2007. Feynman R.P., Przyjemność poznawania, Prószyński i S-ka,Warszawa 2005.

Grobler A., Dwa pojęcia wiedzy: w stronę unifikacji, „Przegląd Filozoficzny — Nowa Seria” 25, 2016, nr 1 (97).

Grobler A., Metodologia nauk, Znak, Kraków 2006.

Hayek F.A. von, Nadużycie rozumu, Prohibita, Warszawa 2013.

Heller M., Granice nauki, Copernicus Center Press, Kraków 2014.

Inhofe J., The Greatest Hoax: How the Global Warming Conspiracy Threatens Your Future, WND Books, Washington, D.C. 2012.

Klementewicz T., Geopolityka trwałego rozwoju: ewolucja cywilizacji i państwa w trakcie dziejotwórczych kryzysów, Dom Wydawniczy Elipsa, Warszawa 2013.

Klementewicz T., Rozumienie polityki: zarys metodologii nauki o polityce, Dom Wydawniczy Elipsa, Warszawa 2011.

Kołakowska A., Wojny kultur i inne wojny, Teologia Polityczna, Warszawa 2015.

Legutko R., Esej o duszy polskiej z posłowiem A.D. 2012, Zysk i S-ka, Poznań 2012.

Lynas M., Six Degrees: Our Future on a Hotter Planet, Fourth Estate, London 2004.

Macała J., Od lekceważenia do trwogi - czyli zmiana klimatu wokót klimatu, „Fabryka wiedzy” 2008, maszynopis w zasobach autora.

Minkner K., O filmach politycznych: między polityka, politycznością i ideologia, Dom Wydawniczy Elipsa, Warszawa 2012.

Mit: Nauka nie jest zgodna w temacie globalnego ocieplenia, http://www.skepticalscience.com/arg_globalne-ocieplenie-konsensus-naukowy.htm (dostęp: 31 października 2016).

Nowak L., U podstaw teorii socjalizmu, t. 1. Własność i władza, o konieczności socjalizmu, Wydawnictwo Nakom, Poznań 1991.

Osiatyński W., Zrozumieć świat. Rozmowy z uczonymi 25 lat później, Czytelnik, Warszawa 2009.

Panasiuk R., Człowiek wobec przyrody, „Acta Universitatis Lodziensis - Folia Philosophica” 1993, nr 10.

Popper K.R., Logika odkrycia naukowego, Wydawnictwo Naukowe PWN, Warszawa 2002.

Popper K.R., Społeczeństwo otwarte i jego wrogowie, t. 2, Wydawnictwo Naukowe PWN, Warszawa 2006.

Popper K.R., Wiedza obiektywna: ewolucyjna teoria epistemologiczna, Wydawnictwo Naukowe PWN, Warszawa 2012.

Schaff A., Obiektywny charakter praw historii: z zagadnień marksistowskiej metodologii historiografii, Państwowe Wydawnictwo Naukowe, Warszawa 1955.

Schmitt C., Teologia polityczna i inne pisma, Społeczny Instytut Wydawniczy Znak, Kraków 2000.

Sussman B., Climategate: A Veteran Meteorologist Exposes the Global Warming Scam, WND Books, Washington D.C. 2010. 
Taleb N.N., Czarny łabędź: o skutkach nieprzewidywalnych wydarzeń, Kurhaus Publishing, Warszawa 2014. Whitehouse D., The Global Warming Standstill, The Global Warming Foundation Report 10, 2013, http://www. thegwpf.org/content/uploads/2013/03/Whitehouse-GT_Standstill.pdf (dostęp: 22 października 2016).

\section{Źródła internetowe}

http://oscar.go.com/news/winners/watch-leonardo-dicaprios-acceptance-speech-for-best-actor-2016 (dostęp: 18 listopada 2016).

http://www.nobelprize.org/nobel_prizes/peace/laureates/2007/ (dostęp: 5 października 2016).

\section{Filmy}

An Inconvenient Truth, prod. USA 2006, reż. D. Guggenheim.

An Inconsistent Truth, prod. USA 2012, scen. i reż. P. Valentine.

Before the Flood, prod. USA 2016, reż. F. Stevens.

\section{The conflict between science and the belief in political and ideological consensus on global warming}

Keywords: global warming, scientific consensus, political consensus, scientific rationality, political rationality

\section{Summary}

This article provides an analysis of conflict between scientific attitude and ideological belief. The consensus on global warming has excluding from Popper's falsifiability. The same issue concerns verification and confirmation on global warming hypothesis. Only three out of a hundred scientists calls into question the theory of climate catastrophe. We don't know if this theory is false, because climatologists and politicians did not accept independent research on global warming. Reduce $\mathrm{CO}_{2}$ emission is dogma of Left-wing politics. The natural sciences are included in the political discourse area. The global warming is a part of ideology and draws people into the area of policy actions. 